\title{
Supplementation of Mangosteen Pericarp Meal and Vitamin E on Egg Quality and Blood Profile of Laying Hens
}

\author{
R. K. Rusli ${ }^{a}$, K. G. Wiryawan ${ }^{\mathrm{b}}$, T. Toharmat ${ }^{\mathrm{b}}$, Jakaria $^{\mathrm{c}}$, \& R. Mutia ${ }^{\mathrm{b}, *}$ \\ aStudy Program of Nutrition and Feed Science, Faculty of Animal Science, Graduate School, \\ Bogor Agricultural University \\ bepartment of Nutrition and Feed Technology, Faculty of Animal Science Bogor Agricultural University \\ 'Department of Animal Production and Technology, Faculty of Animal Science, Bogor Agricultural University \\ Kampus IPB Darmaga, Bogor 16680, Indonesia \\ (Received 06-06-2015; Reviewed 31-07-2015; Accepted 19-10-2015)
}

\begin{abstract}
This research aimed to study the supplementation effects of mangosteen pericarp meal (MPM) and vitamin $\mathrm{E}$ (VE) in the diets on the egg quality and blood profile of laying hens. This research used 160 laying hens of Lohman strains 24 weeks of age. The observation was conducted for 11 weeks. A completely randomized design with four treatments and four replications (10 birds each) was used in this experiment. The treatments consisted of R0 (control diet), R1 (R0 + $1 \mathrm{~g} \mathrm{MPM/kg}$ ration), R2 $(\mathrm{R} 0+2 \mathrm{~g}$ MPM/ $\mathrm{kg}$ ration) and R3 (R0 $+200 \mathrm{mg} \mathrm{VE} / \mathrm{kg}$ ration). Variables measured were egg quality, yolk cholesterol, and blood profiles. The data were analyzed by using analysis of variance (ANOVA) and any significant difference between the treatment means were further tested by Duncan's Multiple Range Test. The results showed that supplementation of $1 \mathrm{~g}$ MPM/kg ration in the diet significantly $(P<0.05)$ decreased blood triglycerides compared with the control, laying hens fed with diet suplemented with of $2 \mathrm{~g} \mathrm{MPM} / \mathrm{kg}$ ration, and laying hens with diet suplemented with $200 \mathrm{mg} \mathrm{VE} / \mathrm{kg}$ ration. Supplementation of MPM and VE did not affect (P>0.05) egg quality (except shell thickness), blood cholesterol, and HDL, respectively. In conclusion, supplementation of $1 \mathrm{~g} \mathrm{MPM} / \mathrm{kg}$ in the diet of laying hens could decrease blood triglycerides.
\end{abstract}

Key words: blood profile, laying hens, mangosteen pericarp meal, egg quality, vitamin E

\begin{abstract}
ABSTRAK
Penelitian ini bertujuan untuk mengkaji pengaruh suplementasi tepung kulit manggis (TKM) dan vitamin E (VE) di dalam ransum pada kualitas telur dan profil darah ayam petelur. Penelitian ini menggunakan 160 ekor ayam petelur strain Lohman umur 24 minggu yang dipelihara selama 11 minggu. Rancangan yang digunakan adalah rancangan acak lengkap dengan 4 perlakuan dan 4 ulangan (10 ekor setiap ulangan). Perlakuan terdiri atas R0 (pakan kontrol), R1 (R0 + $1 \mathrm{~g}$ TKM/kg as fed), R2 (R0 $+2 \mathrm{~g}$ TKM/ $\mathrm{kg}$ as fed), dan R3 (R0 + $200 \mathrm{mg} \mathrm{VE} / \mathrm{kg}$ as fed). Peubah yang diukur adalah kualitas fisik telur, kolesterol telur, dan profil darah. Data yang diperoleh dianalisa secara statistik menggunakan analysis of variance (ANOVA) dan jika terdapat perbedaan nyata antar perlakuan maka dilakukan uji lanjut Duncan's Multiple Range Test. Hasil penelitian menunjukkan bahwa suplementasi $1 \mathrm{~g}$ TKM/kg as fed di dalam ransum menurunkan $(P<0,05)$ trigliserida darah jika dibandingkan dengan kelompok kontrol, ayam petelur yang diberi makan ransum yang disuplementasi $2 \mathrm{~g}$ TKM/kg as fed, dan 200 $\mathrm{mg} \mathrm{VE} / \mathrm{kg}$ as fed. Perlakuan suplementasi TKM dan VE tidak mempengaruhi $(\mathrm{P}>0,05)$ kualitas telur (kecuali tebal kerabang), kolesterol darah, dan HDL. Kesimpulannya, suplementasi $1 \mathrm{~g} \mathrm{TKM} / \mathrm{kg}$ as fed dalam ransum ayam petelur dapat menurunkan kadar trigliserida darah.
\end{abstract}

Kata kunci: profil darah, ayam petelur, tepung kulit manggis, kualitas telur, vitamin E

*Corresponding author:

E-mail: rmutia.1@gmail.com 


\section{INTRODUCTION}

Chicken's egg is one of primary poultry products that can be used as animal protein source with rich nutrient content and easily found by consumers. Egg quality is defined by external and internal properties. External properties include shell cleanliness, color, shape and soundness of shell. Meanwhile, internal properties include, relative viscosity of albumen, yolk shape, yolk color and nutrient content (Hussain et al., 2013). Egg quality recently gains attention not only in farmer level but also in industry and consumer levels. Various aspects such as genetic, nutrient, breeding system, environment and post-harvest handling are interesting studies in order to produce and improve the quality of egg.

Ambient temperature is one of important factors that should be considered in breeding chicken in order to produce good quality of eggs. High temperature in Indonesia may cause flocks to experience heat stress leading to the formation of free radical, productivity and metabolism disorder thereby affecting the quality and quantity of eggs (Gu et al., 2008; Mujahid et al., 2007; Sugito, 2009). Efforts have been done to overcome those problems such as using antioxidant. Recently, mineral and vitamin are commonly used as antioxidants.

Vitamin E (VE) is the major antioxidant component in biological system which plays an important role in metabolism process, protecting cellular structure and maintaining membrane stability from free radical. A number of researches reported that VE is able to fix and increase performance (Ajakaiye et al., 2011; Ciftci et al., 2005), egg production (Bolukbasi et al., 2007; Ciftci et al., 2005; Irandoust et al., 2012), quality of eggs (Ciftci et al., 2005; Jiang et al., 2013), immune system (Asli et al., 2007; Da Silva et al., 2009; Iqbal et al., 2015), and decrease malondialdehyde (Brenes et al., 2008; Goni et al., 2007; Jiang et al., 2013; Voljc et al., 2011) during heat stress.

Mangosteen pericarp is a part of mangosteen fruit which has long been known as a medicine for diarrhea, skin infections as well as for coloring foodstuffs and textiles. The main chemical compound of mangosteen pericarp is xanthone and its derivative (Jung et al., 2006; Kondo et al., 2009; Suksamrarn et al., 2006), anthocyanin (Palapol et al., 2009), saponin and tannin. Some researchers reported that mangosteen compound had an antioxidant (Jung et al., 2006; Kondo et al., 2009; Suvarnakuta et al., 2011), anti-allergic (Chae et al., 2012), anti-cancer (Mizushina et al., 2013), anti-tumor, anti-bacterial and anti-malaria properties (Akao et al., 2008; Gutierrezorozco \& Failla. 2013; Pedraza-Chaveri et al., 2008). Accordingly, a study on the supplementation of the laying hens diets with mangosteen pericarp meal (MPM) and VE was carried out to determine their effects on egg physical quality, egg cholesterol, blood cholesterol, triglyceride and high-density lipoprotein.

\section{MATERIALS AND METHODS}

\section{Design, Animal, and Diet}

This research used 160 laying hens (Lohman strain, Japfacomfeed, Indonesia), aged 24-weeks old. This research used four feeding treatments: R0 (control diet), $\mathrm{R} 1$ (R0 + $1 \mathrm{~g} \mathrm{MPM} / \mathrm{kg}$ ration as fed), R2 (R0 + $2 \mathrm{~g}$ MPM/ $\mathrm{kg}$ ration as fed), $\mathrm{R} 3(\mathrm{R} 0+200 \mathrm{mg} \mathrm{VE} / \mathrm{kg}$ ration as fed) with four replications. Each replication used 10 chickens (2 hens/cage, the dimensions for each cage were $35 \times 36$ x $42 \mathrm{~cm}$ ). Drinking water was provided ad-libitum and feeding was given twice a day i.e in the morning $(07.00$ $\mathrm{am})$ and afternoon $(05.00 \mathrm{pm})$. This research was carried out for 11 weeks. Cage was equipped with lamp for $16 \mathrm{~L} / 8 \mathrm{D}$.

Mangosteen pericarp was obtained from smallholders' estate area in Leuwiliang, Bogor, West Java. MPM was processed by using drying oven during 5-6 h (LTE scientific Swallow, UK) at a temperature of $50^{\circ} \mathrm{C}$, then ground using a disk mill machine (Jiayu Electrical Machinery, Taiwan). VE used in this research was vitamin E, $40 \mathrm{mg} / \mathrm{g} \alpha$-tocopherol acetate (Interchemie, Netherlands).

Feed ingredients consisted of maize, soybean meal, fish meal, coconut oil, $\mathrm{CaCO} 3$, salt, DL-Methionine, and premix. Feed requirement of laying hens was defined by Leeson \& Summers (2005) method with the metabolizable energy content of $2900 \mathrm{kcal} / \mathrm{kg}$ and $17 \%$ crude protein. The Ingredient and nutrient content used in this research are as shown in Table 1. All research procedures had been approved by the animal ethic committee, Bogor Agricultural University No.12-2014 IPB.

Table 1. Ingredient and nutrient contents of basal diets

\begin{tabular}{lc}
\hline Ingredients & Contents \\
\hline Maize (\%) & 55.00 \\
Soybean meal (\%) & 24.00 \\
Fish meal (\%) & 8.50 \\
Coconut oil (\%) & 3.00 \\
CaCO $_{3}(\%)$ & 8.50 \\
Salt (\%) & 0.20 \\
Dl-Methionine (\%) & 0.30 \\
Premix (\%) & 0.50 \\
Nutrient content ${ }^{\mathrm{b}}$ : & \\
Metabolizable energy (kcal/kg) & 2900.75 \\
Crude protein (\%) & 17.19 \\
Crude fiber (\%) & 2.18 \\
Crude fat (\%) & 5.32 \\
Ca (\%) & 3.83 \\
Available P (\%) & 0.49 \\
Methionine (\%) & 0.73 \\
Lysine (\%) & 1.33 \\
Cystine (\%) & 0.34 \\
Tryptophan (\%) & 0.27 \\
Threonine (\%) & 0.95 \\
Arginine (\%) & 1.42 \\
Na (\%) & 0.15 \\
Zinc (mg/kg) & 38.55 \\
\hline
\end{tabular}

Note: ${ }^{\text {Premix }}$ provided (in $\mathrm{mg} / \mathrm{kg}$ premix)= vit A 500,000 IU; vit D 100,000 IU; vit E 150 mg; vit K 50 mg; vit B1 50 mg; vit B2 250 mg; vit B12 $250 \mathrm{mcg}$; niacinamide $375 \mathrm{mg}$; Ca-d-panthotenate 125 $\mathrm{mg}$; folic acid $25 \mathrm{mg}$; choline cloride 5,000 mg; Glysine 3,750 mg; Dl-methionine 5,000 mg; Mg sulphate 1,700 mg; Fe sulphate 1,250 mg; Mn sulphate 2,500 mg; Cu sulphate $25 \mathrm{mg}$; Zn sulphate 500 $\mathrm{mg}$; K iodine $5 \mathrm{mg}$. ${ }^{\mathrm{b}}$ Calculated value. 


\section{Variables Observed}

Physical quality of egg. Physical quality off egg was observed on day 21 after diet treatments. The observation was carried out for five consecutive weeks with eggs were taken randomly. Samples were taken once a week (3 eggs from each replication). Parameters consisted of egg weight $(\mathrm{g})$ measured by using digital scale (Osuka$\mathrm{HWH} \AA$, Japan), percentage of egg shell (\%), yolk (\%), and the albumen (\%). Shell thickness ( $\mathrm{mm}$ ) was measured by using digital caliper (150 Digital Caliper, Nankai ${ }^{\circledR}$, Japan). Haugh unit (HU) were calculated from the records of egg weight and albumen height by using the formula: $\mathrm{HU}=100 \log 10(\mathrm{H}-1.7 \mathrm{~W} 0.37+7.56)$, where $\mathrm{H}=$ height of the albumen $(\mathrm{mm})$, and $\mathrm{W}=$ egg weight $(\mathrm{g})$. Yolk color was determined by comparing the yolk color standard to Egg Roche Yolk Colour Fan (Ovo Color, Aktiengesellscharft BASF, Germany). Shell color was determined by comparing the shell color according to Brown Color Indicator (Max care, Trouw Nutrition International, Netherlands).

Yolk cholesterol. Yolk cholesterol was determined at the end of the study by using one egg for each replication which was taken randomly. Egg cholesterol was analyzed by using Liebermann Burchard method (Burke et al., 1974), the absorbance was read by using spectrophotometer (Hitachi U-2001, Japan) at a wavelength of $(\lambda)$ $420 \mathrm{~nm}$.

Blood high-density lipoprotein, cholesterol and triglycerides. Blood sampling was carried out at the end of the study. Chickens were randomly selected from each treatment (one chicken per replication). Blood was taken as much as $3 \mathrm{ml}$ at the vena jugularis which located in the neck by using a sterile syringe. Blood high-density lipoproteins (HDL) and cholesterol were analyzed by using CHOD-PAD (cholesterol oxidation-phenol-4-aminoantipyrine-peroxidase) method. Triglycerides (TG) level was analyzed by using glycerol-3-phosphate oxidase (GPO) colorimetic method which read at a wavelength $(\lambda)$ of 500 nm using spectrophotometer (Hitachi U-2001, Japan).

\section{Data Analysis}

Data were then statistically analyzed by using Analysis of Variance (ANOVA) by means of Statistical Package for the Social Sciences (IBM ${ }^{\circledR}$ SPSS ${ }^{\circledR}$ version 21.0). Duncan Multiple Range Test (DMRT) was applied to determine the differences among treatments (Steel \& Torrie, 1995). Differences were considered significant at $\mathrm{P}<0.05$.

\section{RESULTS AND DISCUSSION}

\section{Physical Quality of Egg}

The physical quality of egg as resulted of MPM and VE supplementation on hen's diet is shown in Table 2. The results showed that supplementation of MPM $2 \mathrm{~g} /$ $\mathrm{kg}$ ration as fed and VE $200 \mathrm{~g} / \mathrm{kg}$ ration as fed significantly reduced shell weight compared to the control and MPM supplementation of $1 \mathrm{~g} / \mathrm{kg}$ ration as fed $(\mathrm{P}<0.05)$. However, supplementation of MPM and VE in the diet did not affect $(\mathrm{P}>0.05)$ the egg weight, percentage of egg shell, yolk, albumen, yolk color, shell color and haugh unit.

Shell thickness decreased in R3 treatment compared with R0 and R1 treatments. This is possibly due to the interaction of vitamin $\mathrm{E}$ with vitamin D. Excess of VE in the diet can reduce $\mathrm{Ca}$ and $\mathrm{P}$ in the blood and bone (Murphy et al., 1981), absorption and utilization of vitamin $A$ and $D_{3}$ (Leeson \& Summers, 2001). In this case the vitamin $\mathrm{D}$ is dissolved in the unhydrolyzed and possibly nonsolubilized tocopheryl acetate and passes through the gut unabsorbed, consequently impaired bone and shell calcification. The reduced shell thickness did not affect the shell weight in this study.

Percentage of yolk ranged between $23.08 \%-23.88 \%$, while the albumen ranged between 63.88\%-65.01\%. Percentage of yolk and albumen was influenced by the content of protein in the diet. Based on this research, protein content $(17 \%)$ in the diet and feed intake (unpublished data) were not significantly different among treatments. This condition produced similar weight of yolk and albumen, relatively.

Table 2. Physical quality of eggs produced by laying hens suplemented with mangosteen pericarp meal (MPM) and vitamin E (VE)

\begin{tabular}{lrrrr}
\hline \multirow{2}{*}{ Variables } & \multicolumn{3}{c}{ Treatments } \\
\cline { 2 - 5 } & R0 & R1 & R2 & $53.33 \pm 1.27$ \\
\hline Egg weight (g) & $53.91 \pm 1.68$ & $53.79 \pm 0.77$ & $12.27 \pm 0.29$ & $53.69 \pm 1.11$ \\
Egg shell (\%) & $12.19 \pm 0.58$ & $12.24 \pm 0.57$ & $23.69 \pm 0.43$ & $11.91 \pm 0.23$ \\
Yolk (\%) & $23.19 \pm 1.01$ & $23.88 \pm 0.90$ & $64.05 \pm 0.23$ & $23.08 \pm 1.06$ \\
Albumin (\%) & $64.63 \pm 1.19$ & $63.88 \pm 1.24$ & $0.32 \pm 0.01^{\mathrm{ab}}$ & $65.01 \pm 1.08$ \\
Shell thickness (mm) & $0.33 \pm 0.01^{\mathrm{a}}$ & $0.33 \pm 0.00^{\mathrm{a}}$ & $8.27 \pm 0.20$ & $0.31 \pm 0.01^{\mathrm{b}}$ \\
Yolk color & $8.05 \pm 0.37$ & $8.13 \pm 0.36$ & $98.75 \pm 1.47$ & $8.55 \pm 0.45$ \\
Haugh unit & $98.01 \pm 1.41$ & $98.93 \pm 2.44$ & $8.23 \pm 0.47$ & $98.27 \pm 2.79$ \\
Shell color & $8.52 \pm 0.04$ & $8.19 \pm 0.31$ & $8.16 \pm 0.72$ \\
\hline
\end{tabular}

Note: Means in the same row with different superscripts differ significantly $(\mathrm{P}<0.05)$. R0= control feed, $\mathrm{R} 1=\mathrm{R} 0+1 \mathrm{~g} \mathrm{MPM} / \mathrm{kg}$ ration as fed, $\mathrm{R} 2=\mathrm{R} 0+2 \mathrm{~g}$ $\mathrm{MPM} / \mathrm{kg}$ ration as fed, $\mathrm{R} 3=\mathrm{R} 0+200 \mathrm{mg} \mathrm{VE} / \mathrm{kg}$ ration as fed. 
Yolk color is influenced by the type of pigment contained in the diet. The application of MPM and VE in the diet (Table 2) did not increase yolk color score, althought MPM contained pigment which derived from secondary metabolites such as: anthocyanins (Palapol et al., 2009).

Shell color in this study was not affected by the supplementation of MPM and VE. The main factor that affect shell color is biliverdin pigment (Zhao et al., 2006; Wang et al., 2009), phorpyrin (Wang et al., 2009), genetic (Zhang et al., 2005), stress level, age and disease (Aygun, 2014). Brown shell color is influenced by phorpyrin pigment which composed of protophorpyrin, coproporphyrin, pentacarboxylic porphyrin, urophorpyrin and some types of unidentified phorpyrin (Wang et al., 2007). Protophorpyrin pigment is produced during the hemoglobin $(\mathrm{Hb})$ process (Kennedy \& Vevers, 1973). This pigment is transported from the liver to the uterus through the blood. Based on $\mathrm{Hb}$ values (unpublished data), there was a correlation between $\mathrm{Hb}$ and shell color. The increasing of $\mathrm{Hb}$ increased shell color and vice versa.

Haugh units (HU) of egg found in this study was not influenced by the supplementation of MPM and VE. This finding is in accordance with the finding of Irandoust et al. (2012) that the addition of VE $348 \mathrm{IU} / \mathrm{kg}$ does not affect the HU value. HU values in this study ranged between 98.01-98.93 and these values were classified into AA quality i.e. > 72 (Unites State Department of Agriculture, 2000).

\section{Yolk Cholesterol}

Yolk cholesterol as resulted of the supplementation of MPM and VE in the diet is shown in Table 3. The result showed that the supplementation of $1 \mathrm{~g} \mathrm{MPM} /$ $\mathrm{kg}$ ration as fed significantly increased egg cholesterol $(\mathrm{P}<0.05)$. The average value of yolk cholesterol was $\mathrm{R} 0$ (4.91 mg/g), R1 (6.15 mg/g), R2 (5.41 mg/g) and R3 (5.24 $\mathrm{mg} / \mathrm{g})$. Supplementation of $1 \mathrm{~g} \mathrm{MPM} / \mathrm{kg}$ ration as fed increased the egg cholesterol as compared to control, supplementation of $2 \mathrm{~g} \mathrm{MPM} / \mathrm{kg}$ ration as fed and 200 $\mathrm{mg} \mathrm{VE} / \mathrm{kg}$ ration as fed. This is due to the ability of MPM as an antioxidant that can protect lipid (TG, phospholipid and cholesterol). It also can protect protein which role as a precursor for yolk formation that it used for the development of embryo by inhibiting free radical resulted from high temperature that can damage tissue.

Yolk precursor (lipid and lipoprotein) is synthesized in the liver supported by estrogen hormone and then circulated to ovaries by blood for follicle maturation and formation. Cholesterol is classified into lipid which is required by a hen as a source of feed material for small cell (blastoderm) and then used by embryo during hatching and to support growth after hatching (McGraw, 2006).

Cholesterol content of yolk significantly affected the lipid composition of embryonic tissue. Avian embryonic tissue contains unsaturated fatty acids in the fat fraction, thus it requires an effective antioxidant protection. Antioxidant defense tissue of newly hatched birds are composed of fat-soluble antioxidants (vitamin E, carotenoids), water soluble (ascorbic acid and glutathione), and antioxidant enzyme (SOD, GSH-Px and catalase) (Surai, 2003).

\section{Blood Profiles}

The effect of ration supplemented with MPM and VE on cholesterol, TG, and HDL is presented in Table 3. The result showed that MPM supplementation in the diet significantly reduced TG level $(\mathrm{P}<0.05)$. However, MPM and VE supplementation did not affect $(\mathrm{P}>0.05)$ cholesterol and HDL concentrations in the blood.

TG ranged between 522.63-753.9 mg/dl. MPM supplementation in the treatment of R1 and R2 showed lower TG levels compared with R0 and R3 treatment. Low level of TG was due to the influence of antioxidant which contained in MPM diet that inhibited free radical that could interfere TG hydrolysis. Antioxidant contained in MPM is not only $\alpha$-mangosteen (40 ppm), but also there are saponin $(8.24 \mathrm{~g} / 100 \mathrm{~g})$ and tannin (32.49 g/100g). Saponin (0.08 g) and tannin (0.32 g) can reduce TG. In this case tannin can increase the activity of lipoprotein lipase (LPL) enzyme (Kothari et al., 2011). The increasing activity of LPL enzyme will break down TG into glycerol and fatty acids and will be released into the blood vessels to be transferred to the destined cells (Piliang \& Djojosoebagio, 2006). The tolerance limit of tannins in chicken feed is $2.6 \mathrm{~g} / \mathrm{kg}$ (Kumar et al., 2005) and saponins at $4.5 \mathrm{~g} / \mathrm{kg}$ ration (Abbas, 2013).

In R3 treatment, supplementation of vitamin $\mathrm{E}$ in the diet was not able to lower TG level in the blood. R3 resulted higher TG level compared to R0 treatment. The increased TG was relatively followed by the increased VLDL and LDL. On the contrary, the increased of HDL was relatively followed by the decreased of VLDL and LDL, vice versa.

Table 3. Yolk cholesterol, blood cholesterol, triglyceride, and blood high-density lipoproteins (HDL) in laying hens suplemented with mangosteen pericarp meal (MPM) and vitamin E (VE)

\begin{tabular}{lcccr}
\hline \multirow{2}{*}{ Variables } & \multicolumn{4}{c}{ Treatments } \\
\cline { 2 - 5 } & R0 & R1 & R2 & R3 \\
\hline Yolk cholesterol (mg/g) & $4.91 \pm 0.15^{\mathrm{a}}$ & $6.15 \pm 0.31^{\mathrm{b}}$ & $5.41 \pm 0.44^{\mathrm{a}}$ & $5.24 \pm 0.43^{\mathrm{a}}$ \\
Blood cholesterol (mg/dl) & $138.91 \pm 11.24$ & $106.00 \pm 17.89$ & $115.82 \pm 27.87$ & $118.73 \pm 20.25$ \\
Triglyceride (mg/dl) & $730.45 \pm 66.81^{\mathrm{a}}$ & $522.63 \pm 67.71^{\mathrm{b}}$ & $612.65 \pm 118.60^{\mathrm{ab}}$ & $753.09 \pm 84.14^{\mathrm{a}}$ \\
HDL (mg/dl) & $14.89 \pm 1.48$ & $15.75 \pm 1.95$ & $14.00 \pm 1.39$ & $17.58 \pm 3.02$ \\
\hline
\end{tabular}

Note: Means in the same row with different superscripts differ significantly $(\mathrm{P}<0.05)$. $\mathrm{R} 0=\mathrm{control}$ feed, $\mathrm{R} 1=\mathrm{R} 0+1 \mathrm{~g} \mathrm{MPM} / \mathrm{kg}$ ration as fed, $\mathrm{R} 2=\mathrm{R} 0+2 \mathrm{~g}$ $\mathrm{MPM} / \mathrm{kg}$ ration as fed, $\mathrm{R} 3=\mathrm{R} 0+200 \mathrm{mg} \mathrm{VE} / \mathrm{kg}$ ration as fed. 
Table 3 showed that there was a decrease trend in blood cholesterol of hen suplemented with MPM and VE. It is due to MPM and VE act as an antioxidant which can protect lipids from free radicals. Therefore, cholesterol that has been synthesized in the liver during production phase, then carried by the blood in the form of lipoproteins and stored in follicle growing and forwarded to the ovary. MPM absorption in the body is associated with fat digestion in the small intestine (Guiterez-orozco \& Failla, 2013) as well as VE (Surai, 2003).

MPM and VE supplementation in the ration did not affect on HDL (Table 3). In this case, MPM and VE can not increase the synthesis and secretion of HDL in the liver and intestine. The functions of HDL, i.e.: (1) transport LDL cholesterol from peripheral tissues to the liver (reverse cholesterol transport) to be converted in the form of bile salts (Hardinia et al., 2007), (2) storage area for apolipoprotein $\mathrm{C}$ and $\mathrm{E}$ which are needed in the chylomicrons and VLDL catabolism. Apolipoprotein C is a cofactor of lipase lipoprotein and apoliprotein $\mathrm{E}$ is a ligand for the LDL receptor (Adiputro et al., 2013).

\section{CONCLUSION}

Supplementation of $1 \mathrm{~g} \mathrm{MPM} / \mathrm{kg}$ as fed in laying hens diet could reduce TG concentration in the blood. The supplementation of MPM and VE did not affect the egg quality (except shell thickness), blood cholesterol, and HDL.

\section{ACKNOWLEDGEMENT}

The authors would like to thank Directorate General of Higher Education of Indonesia for Beasiswa Unggulan (superior scholarship) and supporting this research through Funding Research Program-BOPTN (Project ID No. 12/IT3/LT/2014).

\section{REFERENCES}

Abbas, T. E. 2013. The use of Moringa oleifera in poultry diets. Turk. J. Vet. Anim. Sci. 37: 492-496. http://dx.doi. org/10.3906/vet-1211-40

Adiputro, D. L., M. A. Widodo, R. Romdoni, \& D. Sargowo. 2013. Extract of mangosteen increases high density lipoprotein levels in rats fed high lipid. Univ. Med. 32:37-43.

Ajakaiye, J. J., A. Perez, \& A. Mollineda. 2011. Effects of high temperature on production in layer chickens supplemented with vitamins C and E. Rev. MVZ Cordoba. 16. 1:22832291

Akao, Y., Y. Nakagawa, M. Iinuma, \& Y. Nozawa. 2008. Anti-cancer effects of xanthones from pericarps of mangosteen. Int. J. Mol. Sci. 9 :355-370. http://dx.doi.org/10.3390/ ijms 9030355

Asli, M. M., S. A. Hosseini, H. Lotfollahian, \& F. Shariatmadari. 2007. Effect of probiotics, yeast, vitamin E and vitamin $C$ supplements on performance and immune response of laying hen during high enviromental temperature. Int. J. Poult. Sci. 6: 895-900. http://dx.doi.org/10.3923/ ijps.2007.895.900

Aygun, A. 2014. The relationship between eggshell colour and egg quality traits in table eggs. Indian J. Anim. Res. 48. 3: 290-294. http://dx.doi.org/10.5958/j.0976-0555.48.3.061
Bolukbasi, S. C., M. K. Erhan, M. S. Keles, \& R. Kocyigit. 2007. Effect of dietary vitamin e on the performance, plasma and egg yolk vitamin e levels and lipid oxidation of egg in heat stressed layers. JABS. 1: 19-23.

Brenes, A., A. Viveros, I. Goni, C. Centeno, S. G. Sayago-Ayerdy, I. Arija, \& F. Saura-Calixto. 2008. Effect of grape pomace concentrate and vitamin $\mathrm{E}$ on digestibilityof polyphenols and antioxidant activity in chickens. Poultry Sci. 87:307-316. http://dx.doi.org/10.3382/ps.2007-00297

Burke, R W., B. I. Diamondstone, R. A. Velapoldi, \& O. Menis. 1974. Mechanisms of the liebermann-burchard and zak color reactions for cholesterol. Clin. Chem. 20. 7:794-801.

Ciftci, M., O. N. Ertas, \& T. Guler. 2005. Effects of vitamin E and vitamin $\mathrm{C}$ dietary supplementationon egg production and egg qualityof laying hens exposed to a chronic heat stress. Revue Med. Vet. 156: 107-111.

Chae, H. S., S. R. Oh, H. K. Lee, S. H. Joo, \& Y. W. Chin. 2012. Mangosteen xanthones, $\alpha$-and $\gamma$-mangostins, inhibit allergic mediators in bone marrow-derived mast cell. Food Chem. 134: 397-400. http://dx.doi.org/10.1016/j.foodchem.2012.02.075

Da Silva, I. C. M., A. M. L. Ribeiro, C. W. Canal, C. C. Pinheiro, M. de Moraes Vieira, T. A. Goncalves, R. A. Pereira, \& L. Lacerda. 2009. Broiler chicken responses to immunologicalstimuli as mediated by different levelsof vitamin $\mathrm{E}$ in the diet. J. Appl. Poult. Res. 18 :752-760. http://dx.doi. org/10.3382/japr.2009-00055

Goni, I., A. Brenes, C. Centeno, A. Viveros, F. Saura-Calixto, A. Rebole, I. Arija, \& R. Estevez. 2007. Effect of dietary grape pomace and vitamin $\mathrm{E}$ on growth performance,nutrient digestibility, and susceptibility to meat lipid oxidation in chickens. Poultry Sci. 86:508-516. http://dx.doi. org/10.1093/ps/86.3.508

Gu, X. H., S. S. Li, \& H. Lin. 2008. Effects of hot environment and dietary protein level on growth performance and meat quality of broiler chickens. Asian Australas. J. Anim. Sci. 21:1616-1623.

Gutierrez-Orozco, F. \& M. L. Failla. 2013. Biological activities and bioavailability of mangosteen xanthones: a critical review of the current evidence. Nutrients 5: 3163-3183. http://dx.doi.org/10.3390/nu5083163

Hardinia, D., T. Yuwanta, Supadmo, \& Zuprizal. 2007. Pengaruh telur beromega-3 dan 6 hasil olahan terhadap profil lipid darah tikus Rattus norvegicus L. normal dan hiperkolesterolemia. Med. Pet. 30. 1:26-34.

Hussain, S., Z Ahmed, M. N. Khan, \& T. A. Khan. 2013. A study on quality traits of chicken eggs collected from different areas of karachi. Sarhad J. Agric. 29: 255-259.

Iqbal, Z., Z. Kamran, J. I. Sultan, A. Ali, S. Ahmad, M. I. Shahzad, U. Ahsan, S. Ashraf, \& M. U. Sohail. 2015. Replacement effect of vitamin $\mathrm{E}$ with grapepolyphenols on antioxidant status, immune, andorgans histopathological responses in broilers from1- to 35-d age. J. Appl. Poult. Res. 24:127-134. http://dx.doi.org/10.3382/japr/pfv009

Irandoust, H, A. H. Samie, H. R. Rahmani, M. A. Edriss, \& G. G. Mateos. 2012. Influence of source of fat and supplementation of the diet with vitamin $\mathrm{E}$ and $\mathrm{C}$ on performance and egg quality of laying hens from forty four to fifty six weeks of age. Anim. Feed Sci. Technol. 177:75-85. http:// dx.doi.org/10.1016/j.anifeedsci.2012.06.004

Jiang, W., L. Zhang, \& A. Shan. 2013. The effect of vitamin E on laying performance and egg quality in laying hens fed corn dried distillers grains with solubles. Poultry Sci. 92 :2956-2964. http://dx.doi.org/10.3382/ps.2013-03228

Jung, H. A., B. N. Su, W. J. Keller, R. G. Mehta, \& A. D. Kinghorn. 2006. Antioxidant xanthones from the pericarp of garcinia mangostana (Mangosteen). J. Agric. Food Chem. 54:2077-2082. http://dx.doi.org/10.1021/jf052649z

Kennedy, G. Y, \& H. G. Vevers. 1973. Eggshell pigments of the 
araucano fowl. Comp. Biochem. Physiol. B 44: 11-25.

Kondo, M., L. Zhang, H. Ji, Y. Kou, \& B. Ou. 2009. Bioavailability and antioxidant effects of a xanthone-rich mangosteen (garcinia mangostana) product in humans. J. Agric. Food Chem. 57: 8788-8792. http://dx.doi.org/10.1021/jf901012f

Kothari, S., A. K. Jain, S. C. Mehta, \& S. D Tonpay. 2011. Hypolipidemic effect of fresh triticum aestivum (wheat) grass juice in hypercholesterolemic rats. Acta Pol. Pharm. 68: 291-294.

Kumar, V., A.V. Elangova, \& A. B. Mandal. 2005. Utilization of reconstituted high-tanin sorgum in the diets of broiler chicken. Asian Australas J. Anim. Sci. 18: 538-544.

Leeson, S, \& J. D. Summers. 2001. Nutrition of the Chicken. 4th ed. University Books. Guelph, Ontario.

Leeson, S. \& J. D. Summers. 2005. Commercial Poultry Nutrition. $3^{\text {rd }}$ ed. University Books. Guelph, Ontario.

McGraw, K. J. 2006. Dietary carotenoids mediate a trade-off between egg quantity and quality in Japanese quail. Ethol. Ecol. Evol. 18: 247-256. http://dx.doi.org/10.1080/08927014 .2006 .9522712

Mizushina, Y., I. Uriyama, T. Nakahara, Y. Kawashima, \& H. Yoshida. 2013. Inhibitory effects of $\alpha$-mangostin on mammalian DNA polymerase, topoisomerase, and human cancer cell proliferation. Food Chem. Toxicol. 59: 793-800. http://dx.doi.org/10.1016/j.fct.2013.06.027

Mujahid, A., Y. Akibaa, C. H. Warden, \& M. Toyomizu. 2007. Sequential changes in superoxide production, anion carriers and substrate oxidation in skeletal muscle mitochondria of heat-stressed chickens. FEBS Letters 581:3461-3467. http://dx.doi.org/10.1016/j.febslet.2007.06.051

Murphy, T. P., K. E. Wright, \& W. J. Pudelkiewicz. 1981. An apparent rachitogenic effect of excessive vitamin $\mathrm{E}$ intakes in the chick. Poultry. Sci. 60:1873-1878. http://dx.doi. org $/ 10.3382 /$ ps.0601873

Palapol, Y., S. Ketsa., D. Stevensonb, J.M. Cooney, A.C. Allan, \& I. B. Ferguson. 2009. Colour development and quality of mangosteen (Garcinia mangostana L.) fruit during ripening and after harvest. Postharvest Biol. Technol. 51:349-353. http://dx.doi.org/10.1016/j.postharvbio.2008.08.003

Pedraza-Chaverri, J., N. Cardenas-Rodriguez, M. OrozcoIbarra, \& J. M. Perez-Rojas. 2008. Medicinal properties of mangosteen (Garcinia mangostana). Food Chem. Toxicol. 46:3227-3239. http://dx.doi.org/10.1016/j.fct.2008.07.024

Piliang, W. G. \& S. Djojosoebagio. 2006. Fisiologi Nutrisi. Vol. 1. IPB Press. Bogor.
Steel, R. G. D. \& J. H. Torrie. 1995. Prinsip dan Prosedur Statistika. Terjemahan: B. Sumantri. Gramedia, Jakarta.

Sugito. 2009. Profil hematologi dan pertambahan bobot badan harian ayam broiler yang diberi cekaman panas pada suhu kandang yang berbeda. Agripet 9: 10-14.

Suksamrarn, S., O. Komutiban, P. Ratananukul, N. Chimnoi, N. Lartpornmatulee, \& A. Suksamrarn. 2006. Cytotoxic prenylated xanthones from the young fruit of garcinia mangostana. Chem. Pharm. Bull. 54:301-305. http://dx.doi. org/10.1248/cpb.54.301

Suprijatna, E., U. Atmomarsono, \& R. Kartasudjana. 2005. Ilmu Dasar Ternak Unggas. Penebar Swadaya, Jakarta.

Surai, P. F. 2003. Natural Antioxidants in Avian Nutrition and Reproduction. Nottingham University Press. Nottingham, UK.

Suvarnakuta, P., C. Chaweerungrat, \& S. Devahastin. 2011. Effects of drying methods on assay and antioxidant activity of xanthones in mangosteen rind. Food Chem. 125:240247. http://dx.doi.org/10.1016/j.foodchem.2010.09.015

USDA. 2000. Egg-Grading Manual. Washington.

Voljc, M., T. Frankic, A. Levart, M. Nemec, \& J. Salobir. 2011. Evaluation of different vitamin $\mathrm{E}$ recommendations and bioactivityof $\alpha$-tocopherol isomers in broiler nutrition by measuring oxidativestress in vivo and the oxidative stability of meat. Poultry Sci. 90 :1478-1488. http://dx.doi. org/10.3382/ps.2010-01223

Wang, X. T., C. J. Zhao, J. Y. Li, G. Y. Xu, L. S. Lian, C. X. Wu, \& X. M. Deng. 2009. Comparison of the total amount of eggshell pigments in Dongxiang brown-shelled eggs and Dongxiang blue-shelled eggs. Poultry Sci. 88 :1735-1739. http://dx.doi.org/10.3382/ps.2008-00434

Wang, X. T., X. M. Deng, C. J. Zhao, J.Y. Li, G. Y. Xu, L. S. Lian, \& C. X. Wu. 2007. Study of the deposition process of eggshell pigments using an improved dissolution method. Poultry Sci. 86:2236-2238. http://dx.doi.org/10.1093/ps/86.10.2236

Zhao, R., G. Y. Xu, Z. Z. Liu, J. Y. Li, \& N. Yang. 2006. A study on eggshell pigmentation: biliverdin in blue-shelled chickens. Poultry Sci. 85:546-549. http://dx.doi.org/10.1093/ ps/85.3.546

Zhang, 1. C., Z. H. Ning, G. Y. Xu, Z. C. Hou, \& N. Yang. 2005 Heritabilities and genetic and phenotypic correlations of egg quality traits in brown-egg dwarf layers. Poultry Sci. 84:1209-1213. http://dx.doi.org/10.1093/ps/84.8.1209 